\title{
腰椎椎間板ヘルニアにおけるクリニカルパスについて
}

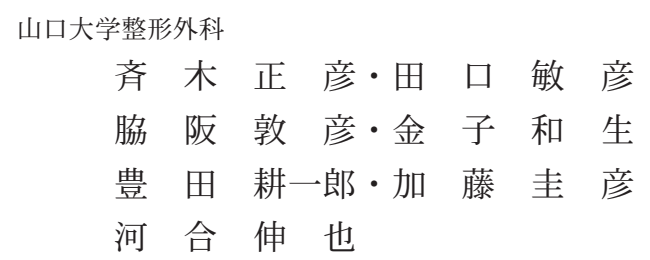

\section{Clinical Path for Lumbar Disc Herniation}

\author{
Masahiko Saiki, Toshihiko Taguchi, Atsuhiko Wakisaka, \\ Kazuo Kaneko, Koichiro Toyota, Yoshihiko Kato, \\ and Shinya Kawai \\ Department of Orthopaedic Surgery, \\ Yamaguchi University School of Medicine, Ube, Yamaguchi, Japan
}

\begin{abstract}
We examined cases of adapted clinical pathway for herniated lumbar disk. A total of 43 patients underwent programmed partial laminectomy or osteoplastic hemi laminectomy. For partial laminectomy, patients were programmed to start walking three days after operation, and leave hospital at 14 days postoperatively. For osteoplastic hemi laminectomy, patients were programmed to start walking at five days, and leave hospital at 21 days postoperatively. Satisfaction index for the operation was generally high. Most of the patients wanted to start walking earlier than we programmed, and when slight variances happened after the patients started walking, we could change the clinical pathway. However, since satisfaction index was low for the length of hospital stay, we must consider how to use clinical pathways appropriately by collecting EBM.
\end{abstract}

Key words : clinical pathway（クリニカルパス), herniated lumbar disk (腰椎椎間板ヘルニ ア), satisfaction index (満足度), evidence based medicine (EBM)

\section{は じめに}

当科においては 2000 年より人工股関節置換術 （THA）にクリニカルパス（以下 $\mathrm{CP}$ と省略する）を 導入して以来, 関節外科, 脊椎外科を中心に適用を拡 大している. 今回, 私たちは腰椎椎間板へルニアにお けるCPについて，検討したので報告する.

\section{対象と方 法}

最近, CP を適用した腰椎椎間板へルニア 43 例で, 男性 27 例, 女性 16 例, 手術時平均年齢は 45.7 歳
（男性 18〜 70 歳，女性 19〜 71歳）であった。手術方 法は, 単一神経根症状を有する春柱管内ヘルニア突出 症例には椎弓部分切除術 (以下 Love 変法と省略する) を選択し，外側へルニアを有する症例には骨形成的偏 側椎弓切除術を施行し，それぞれ 28 例, 15 例であつ た.

後療法については, Love 変法は, 術後 3 日で離床, 7 日目より理学療法を開始し, 術後 14 日で退院を目 安としている(図 1).

Love 変法における術後平均在院日数は 18 日であつ た. バリアンスは, 離床時期に関しては生じなかった 


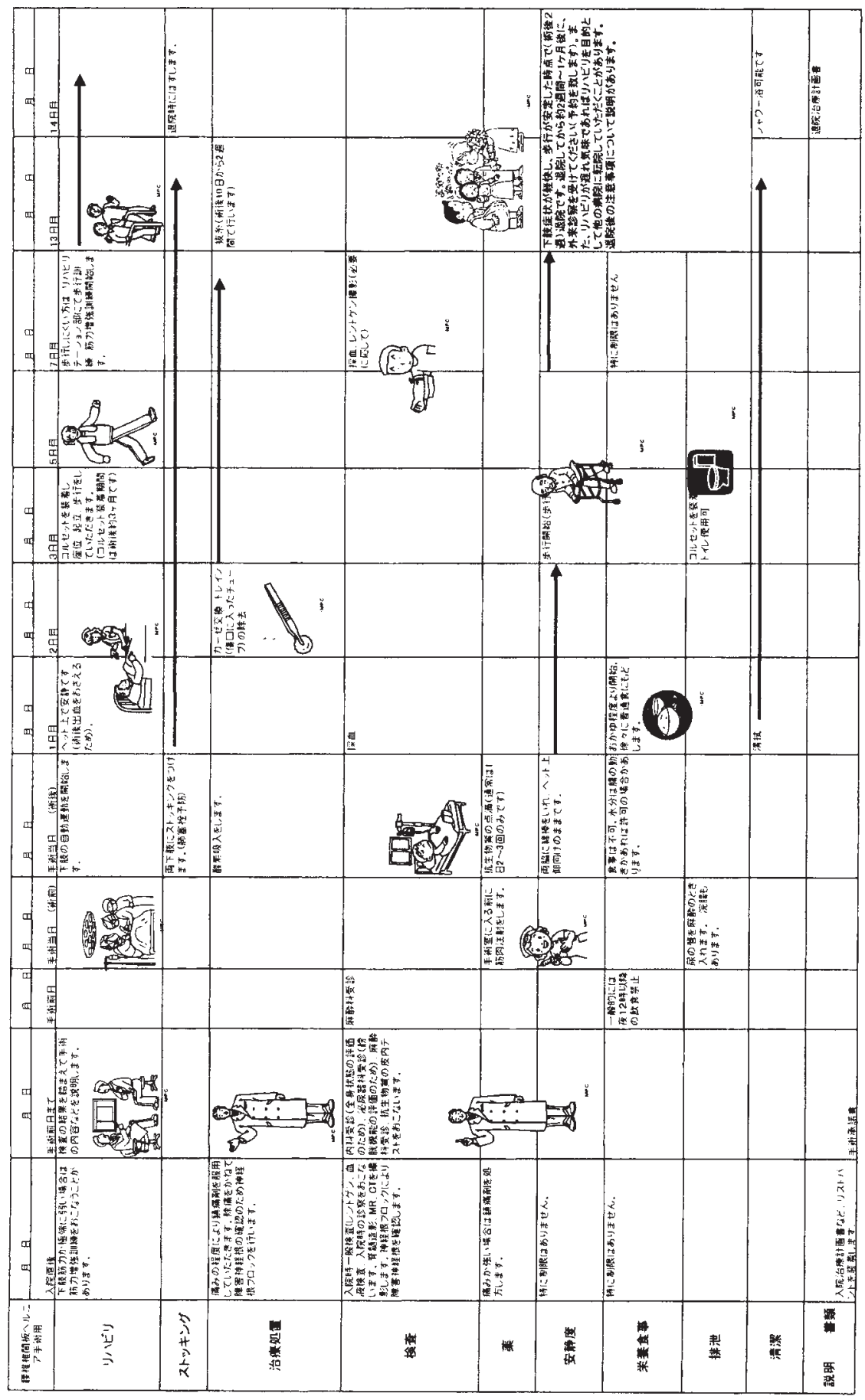

図 1 LOVE 変法のクリニカルパス 


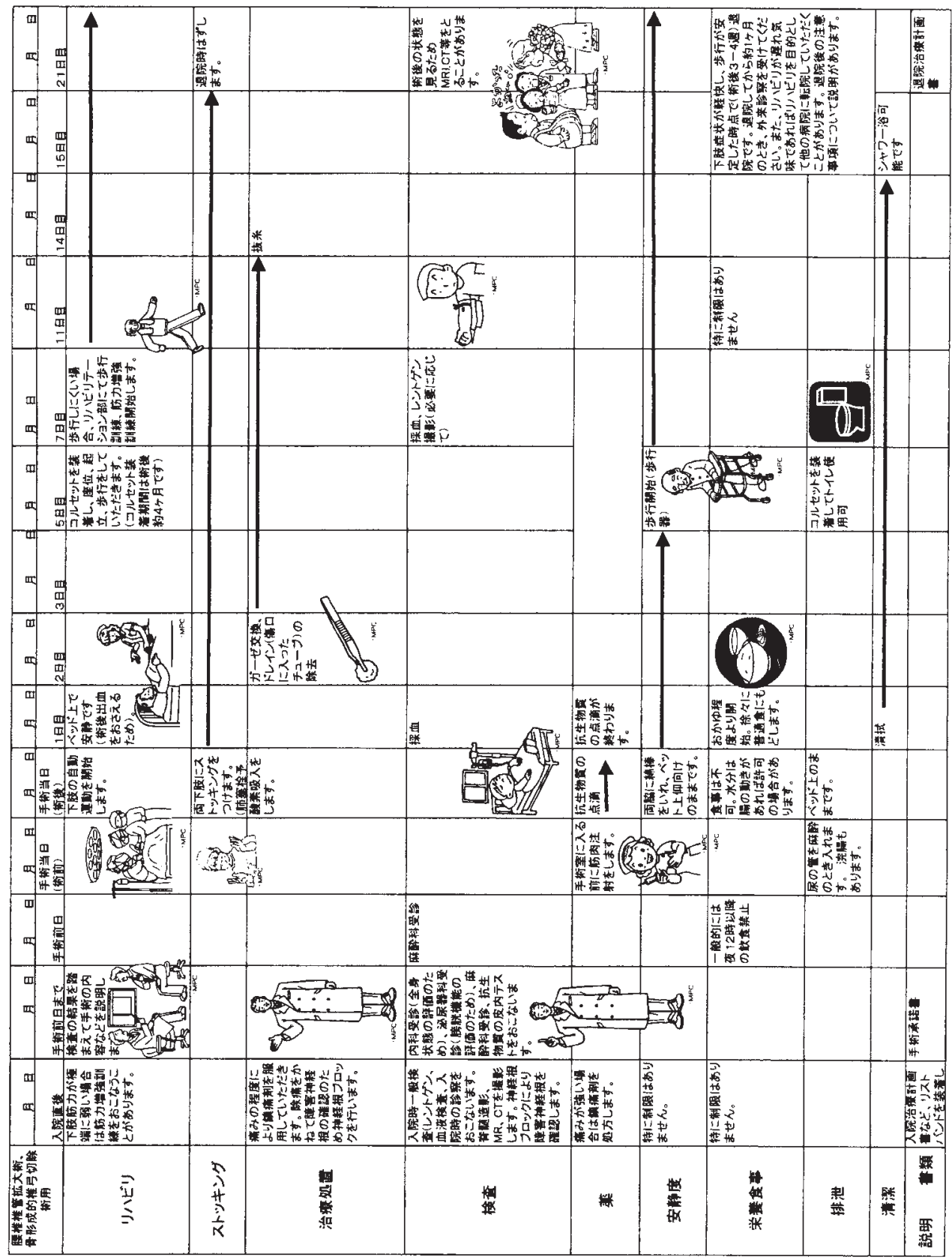

図 2 骨形成的椎弓切除術のクリニカルパス 
が，在院日数において 2 例生じた. 原因としては, 2 例とも 60 歳代で, 1 例は家庭・社会的問題のため, もう 1 例は, 術前症状残存し不安が残つたためであつ た.

骨形成的偏側椎弓切除術においては, 術後 5 日で離 床, 7 日目より理学療法を開始し術後 21 日で退院を 目安としている（図 2).

骨形成的椎弓切除術における術後平均在院日数は 26 日だった。 バリアンスは，離床時期遅延が 2 例で あり，原因は術中の骨の適合性不良で，固定性が十分 得られなかったためであった。

また，CP 導入に対する Patient Satisfaction（以 下 PS）を患者 40 人に対してアンケートにより調査 した. 検討項目は，1）術前の検査・説明について,

2） CP を使用する事に関して，3）術後離床時期につ いて，4）退院時期について，5）再度，入院した場合 での CP の使用について，6）術後離床時期の症状改 善度について行つた.

\section{結果}

術前の検査・説明については, PS は 95\%であつた. CP を使用する事に関しても同様に PS は 88\%であっ た.

術後離床時期については, 丁度良いとする意見が 62 \%であった反面，遅いという意見も $28 \%$ にられた.

退院時期については，丁度良いと，早いとする意見 が $47 \%$ で同等だった。再度，入院した場合での CP の使用については，使用したいという意見が $77 \%$ で あった. 術後離床時期における症状の有無を術前との 症状と比較すると, 術後症状改善度が $80 \%$ 未満と回 答した割合は $16 \%$ であった。 1 例が 2 度目の手術で不 安があつたこと，3例が術前の下肢痺れ残存したこと， 4 例が術前存在していた筋力低下の回復が不十分であつ たことを満足度が低い理由としてあげていた。

\section{考察}

腰椎椎間板へルニアにおける術後離床時期について は，1日から 4 日 (13)45)6) と様々である. 当科では， Love 変法で 3 日, 骨形成的偏側椎弓切除術で 5 日と し，この設定ではバリアンスの発生は少数だったが, PS では，28\%が離床時期が遅いという意見だった。

離床時期と術後症状改善度の関係をみると, 術後症
状改善度が 100 から 80 の患者も， 80 末満の患者も， 同程度の割合で，離床時期が遅いと返答している。す なわち, 症状改善度の有無に関わらず, 患者は早期離 床を希望していた．加えて離床時のバリアンスが少な かったことから, 今後, 腰椎椎間板ヘルニアにおける 後療法では早期離床が可能であると結論している.

退院時期については，7 日から 14 日 $^{1334) 5(6)}$ と様々で ある. 当科では, Love変法で 14 日, 骨形成的偏側椎 弓切除術で 21 日とし, バリアンスの発生も少数であつ たが，PSにおいては，47\%で退院時期が早いという 意見だった．退院時期が早いと答えたのは 47\%で, そのうちの $30 \%$ が早いと感じたが満足しており，70 \%が入院期間の延長を希望していた。この事から EBM に基づき，患者の理解に向けての説明・同意を する必要がある。

また CP を使用したことに対し，済生会熊本病院が 使用したアンケートを基に2 医療スタッフ 40 人にア ンケートを行い，その結果を検討した。 医療スタッフ 側の評価は, 各スタッフ間の共通認識について, イン フォームドコンセントに関しても満足度は高かった。 業務の質，チーム医療，職員教育に関しては，満足度 はやや低めであった．アンケート結果からは，CP の 目的である患者中心の医療のためには有効であり，ま た，CPによってスタッフ間の共通認識が高まり，チー ム医療に参加しているという自覚が生まれ，リスクマ ネージメントの低下へ慗がると思われた.

CP 導入による患者の意見としては，術前の検査・ 説明については，5\%で事務的な印象を受けると返答

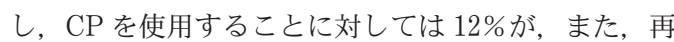
度，入院した場合での CP の使用については $23 \% か ゙ ，$ CPから外れた時が不安という返答が多かった。

$$
\text { ま と め }
$$

(1)腰椎椎間板ヘルニアの CP を検討した.

(2)CP を使用する事に関しては，総じて PS は高かっ た.

(3)バリアンスの発生は少数のため, 術後の離床時期 を早めることが可能であった.

(4)退院時期を早める事に関しては，PS は低かつた が，今後エビデンスを集め検討して行く予定である.

(5)少数意見も考慮しながら CP を活用する必要があ る。 


\section{参 考 文 献}

1）芦沢僚平：広範椎弓切除術. NEW MOOK 整形外科,

9 腰部脊柱管狭窄症 : 148-158, 2001.

2）今村治男ほか：クリニカルパス運用の効果判定. クリ 二カルパス運用事例集 : 49-62, 2001.

3）千田治道ほか：腰椎後方固定術. クリニカルパス実例
集: 64-69, 1999.

4) 米 和徳ほか: 経皮的椎間板摘出術のクリニカルパス. 整形と災害, $45: 885-889,2002$.

5）米 和徳ほか：腰椎椎間板へルニア再発例に対する経 皮的椎間板摘出術. 整形外科, $44: 1795-1800,1993$.

6) 渡辺栄一：腰椎椎間板ヘルニア. 脊椎の手術 I : 118128, 1996. 